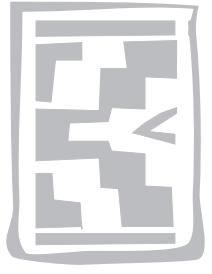

\title{
The effect of GnRH or oestradiol injected at pro-oestrus on luteal function and follicular dynamics of the subsequent oestrous cycle in non-lactating cycling Holstein cows
}

\author{
B.V.E. SEGWAGWE ${ }^{1 *}$, K.L. MACMILLAN ${ }^{2}$ and P.D. MANSELL ${ }^{2}$
}

\begin{abstract}
SEGWAGWE, B.V.E., MACMILLAN, K.L. \& MANSELL, P.D. 2006. The effect of GnRH or oestradiol injected at pro-oestrus on luteal function and follicular dynamics of the subsequent oestrous cycle in non-lactating cycling Holstein cows. Onderstepoort Journal of Veterinary Research, 73:61-70

Oestrous synchronization involves synchronization of ovarian follicular turnover, new wave emergence, and finally induction of ovulation. The final step can be synchronized by the parenteral administration of either $\mathrm{GnRH}$ or oestradiol benzoate. This study investigated corpus luteum and follicular emergence after ovulation had been induced by the administration of either $\mathrm{GnRH}$ or oestradiol benzoate. The injection of oestradiol benzoate may have delayed the emergence of the first follicular wave subsequent to the induced ovulation; administration of oestradiol benzoate or $\mathrm{GnRH}$ lowered the progesterone rise so that the maximum dioestrous concentration of progesterone on Day 9 was lower when cows were treated during pro-oestrus compared to the spontaneously ovulating controls. One implication of findings from the present study is that induction of ovulation with either oestradiol benzoate or $\mathrm{GnRH}$, administered 24 or $36 \mathrm{~h}$ after withdrawal of the CIDR device, respectively, may lower fertility. Future studies must identify the timing of administration relative to the time of CIDR device withdrawal and the optimum concentration of oestradiol benzoate or GnRH that would not have untoward effects on the development of the corpus lutea, particularly within the first week of dioestrus.
\end{abstract}

Keywords: Corpus luteum, GnRH, oestradiol benzoate, ovarian follicles, ovulation, progesterone

\section{INTRODUCTION}

Induction of ovulation with $\mathrm{GnRH}$ is used in the Ovsynch protocol (Pursley, Wiltbank, Stevenson, Ottobre, Garverick \& Anderson 1997); it has also been used at the end of a protocol where the initial treatment used was a combination of intra-vaginal progesterone releasing device containing $1.9 \mathrm{~g}$ of progesterone (CIDR device) and $5 \mathrm{mg}$ oestradiol

* Author to whom correspondence is to be directed

1 Applied Neurobiology Group, Faculty of Veterinary Medicine, University of Glasgow, 464 Bearsden Road, Glasgow, G61 1QH, UK. E-mail: besegwagwe@yahoo.co.uk

2 The University of Melbourne, Veterinary Clinical Centre, 250 Princess Highway, Werribee, 3030, VIC Australia

Accepted for publication 9 November 2005-Editor benzoate (Rivera, Goni, Chaves, Ferrero \& Bo 1998). The proportion of cows ovulating within $24-48 \mathrm{~h}$ of using $\mathrm{GnRH}$, tended to be higher in the group of cows where the initial treatment was a combination of progesterone and oestradiol benzoate, compared to where either a CIDR devise or calf removal was used (Rivera et al. 1998). Emergence of a new follicular wave can be synchronized by the injection of oestradiol benzoate at the time of CIDR insertion (Adams 1998). This explains the synchronous induction of ovulation with $\mathrm{GnRH}$ at the end of a treatment regime that involved the CIDR device and oestradiol benzoate (Rivera etal. 1998). Interestingly, the function of the corpus luteum that formed as a sequel to this ovulation depended on the stage of development of the ovulatory follicle at the time of the induction of the ovulation; a corpus luteum formed after the ovulation of the dominant follicle that were 
at the growing or early static phase at the time of $\mathrm{GnRH}$ administration maintained the highest concentration of plasma progesterone compared to cows ovulating spontaneously (Rivera et al. 1998).

Oestradiol benzoate is frequently used to induce ovulation and reduce the interval and variation of onset of oestrus (Day, Burke, Taufa, Day \& Macmillan 2000). More than $90 \%$ of cows came into oestrus within 3 days of induction of ovulation with oestradiol benzoate (Day et al. 2000). This synchronized occurrence of oestrus allows fixed-time insemination with resulting conception rates in heifers so inseminated within $48 \mathrm{~h}$ approaching 50\% (Hanlon, Williamson, Wichtel, Steffert, Craigie \& Pfieffer 1996). A typically normal corpus luteum was formed after treatment of anovulatory anoestrous beef cows with progesterone and induction of ovulation with oestradiol benzoate (Fike, Day, Inskeep, Kinder, Lewis, Short \& Hafs 1997).

Recruitment of a new wave of follicles occurred earlier after induction of ovulation with $\mathrm{GnRH}$ given $24 \mathrm{~h}$ after prostaglandin F2 $\alpha$ (PGF2 $\alpha$ ), compared to untreated controls (Taponen, Katila \& RodriguezMartinez 1999), although induction of ovulation with $\mathrm{GnRH}$ may also be associated with shortened luteal lifespan (Taponen et al. 1999) and reduced pregnancy rates (Schmitt, Diaz, Drozt \& Thatcher 1996). While an injection of $\mathrm{GnRH}$ during metoestrus did not affect the development of the corpus luteum when compared to that in untreated controls (Taponen, Rodriguez-Martinez \& Katila 2000) it did cause a predictable release of leutinizing hormone (LH) and a significant increase in serum progesterone due to an increase in the proportion of large luteal cells on Day 10 (Mee, Stevenson, Alexander \& Sasser 1993). Luteal plasma progesterone concentration may be decreased after induction of ovulation with a $\mathrm{GnRH}$ agonist compared to that which occurs after spontaneous oestrus (Lucy \& Stevenson 1986).

Peters, Ward, Warren, Gordon, Mann \& Webb (1999) compared the effect of $\mathrm{GnRH}$ and spontaneous ovulation (control) in an Ovsynch protocol on post-ovulation luteal function. Plasma progesterone concentrations increased more rapidly in the $\mathrm{GnRH}$ group than in the control group and were significantly higher on Days 3 and 4 after ovulation. The size of the pre-ovulatory follicle has been positively correlated with the plasma concentrations of progesterone post-ovulation (Moreira, De la Sota, Diaz \& Thatcher 2000).

There is no other information in the literature where a comparison of the post-ovulation corpus luteum and follicular development after treatment with oestradiol benzoate or $\mathrm{GnRH}$ at pro-oestrus was made in the same trial. It was therefore hypothesized that the injection of oestradiol benzoate at pro-oestrus would cause delayed emergence of the first postovulation follicular wave and that post-ovulatory corpus luteum development and plasma progesterone concentrations would be similar in cows induced to ovulate with either oestradiol benzoate or $\mathrm{GnRH}$.

\section{MATERIALS AND METHODS}

\section{Experimental design and treatment of animals}

Each cow in a group of 14 non-lactating cycling Holsteins was injected intramuscularly with $25 \mathrm{mg}$ of PGF2-alpha (Lutalyse ${ }^{\circledR}$, Pharamacia \& Upjohn) on Day -17 (where Day 0 was the day of ovulation which was defined as the day on which an ovulatory follicle was last seen). A CIDR $®$ device (Genetics Australia, Bacchus Marsh, Victoria), was inserted into the vagina of every cow on Day -10 , and left in situ for 8 days. Every cow was injected intramuscularly with $2 \mathrm{mg}$ oestradiol benzoate (CIDIROL $\AA$, Genetics Australia) on that day and then with a further $25 \mathrm{mg}$ of PGF2a on Day -2 . This was where the CIDR devices were withdrawn.

The cows were randomly allocated to three subgroups ( $n=5$ Sub-group A; $n=5$ Sub-group B; $n=$ 4 Sub-group C). In Round 1, cows in Sub-group A were each injected intramuscularly with $1 \mathrm{mg}$ oestradiol benzoate, $24 \mathrm{~h}$ after CIDR device removal, (Day -1 ), while every cow in the Sub-group B was injected intramuscularly with $250 \mu \mathrm{g} \mathrm{GnRH}$ analogue (Fertagy $\mid 囚$, Intervet Australia) $36 \mathrm{~h}$ after CIDR device removal. Cows in Sub-group $C$ received no further pro-oestrous treatment.

The entire treatment procedure was repeated three times in a cross over design with each of the 14 cows receiving one of the three pro-oestrous treatments at a given round. A new CIDR device was inserted into the vagina of every cow on Day 11 of each round, and an intramuscular injection of $2 \mathrm{mg}$ oestradiol benzoate on the same day so that Day 10 of one round was Day 11 of the preceding round. Each sub-group received the three pro-oestrous treatments following the same direction of order so that there were three sequences of the pro-oestrous treatments for the entire duration of the experiment, as shown in Table 1.

Oestrus was observed using Heatwatch $\AA$ (DDx Incorporated, Denver, USA, www.heatwatch.com), 
over a 72-h period beginning on the day of CIDR removal. However, the Heatwatch $®$ was left on and recorded for the entire duration of the experiment.

\section{Ultrasonography}

Sequential examination of structures on the ovary of every cow was completed using an $7.5 \mathrm{MHz}$ real time B-mode transrectal transducer connected to an ultrasound (Aloka SSD-500®, Aloka, Tokyo, Japan). This daily examination commenced on Day -5 and ended on Day 10 of each round. Measurements of ovarian structures included the location and diameter of the follicles $(\mathrm{mm})$, particularly those with a diameter of $4 \mathrm{~mm}$ or more, the location and the diameter of the corpus luteum. The growth rate of the first dominant follicle was defined as the change in diameter during the time interval from emergence until Day 10, which was calculated by taking the difference in the diameter of the dominant follicle between day of emergence and Day 10 divided by the number of days from emergence to Day 10.

Ovulation was assumed to have occurred for an individual cow, after the disappearance of a follicle measuring over $8 \mathrm{~mm}$ in diameter, followed by the appearance of a corpus luteum at this site, as well as an increase in plasma progesterone concentration.

\section{Blood sampling}

Whole blood samples (10 $\mathrm{m} \ell$ ) were collected from the coccygeal vein of every cow every alternated day from Day -5 until Day 9 (except for the catheterised cows on the days of intensive jugular bleeds (Days -1 and 0 ). This sample was collected into a heparinised tube using a 22-gauge sterile venipuncture needle. Plasma was separated using a centrifuge (Clements SG $400 \circledast$, Clements, Sydney, NSW, Australia) at $2000 \mathrm{rpm}$ for at least $15 \mathrm{~min}$. The plasma was pipetted into 5-m $\ell$ plasma tubes in duplicates and stored immediately at $-20^{\circ} \mathrm{C}$ until assayed. Just prior to assaying, the plasma samples were thawed in a cold room, at $2.5^{\circ} \mathrm{C}$ overnight

In addition, an intravenous catheter was surgically inserted into the jugular vein of each of the six cows on Day -2 , comprising of two cows per treatment sub-group. Each of these selected six cows was placed in an individual pen. The whole blood $(10 \mathrm{~m} \ell)$ was collected from the catheterised jugular vein at $0,4,8,12,14,16,20,24$ and $36 \mathrm{~h}$ relative to the time $(\mathrm{T})$ of oestradiol benzoate treatment (T0, T4, T8, T12, T14, T16, T20, T24 and T36, respectively). Plasma was separated, transferred into plasma tubes and stored until further assaying. The catheters were withdrawn from the jugular vein of each of the six cows after the last jugular bleed ( $36 \mathrm{~h})$; at this time these cows were removed from the individual pens to join the rest of the cows in the trial.

\section{Hormonal assays}

\section{Progesterone}

A commercial radioimmunoassay kit specific for progesterone was used (Spectria® Progesterone 125-I Coated Tube Radioimmunoassay, Orion Diagnostica, Finland). The principle of the test is that progesterone in the "unknown" samples competes with 125-I labelled progesterone tracer, for binding sites on tubes coated with polyclonal rabbit progesterone antibodies. A gamma counter, Packard Auto-Gamma 5780® (United Technologies, Packard, Australia) was used to measure 125-I progesterone bound to the polyclonal rabbit progesterone antibodies in the test tube. The progesterone concentrations (standards in bovine steer plasma and unknown samples) and quality control data were determined by the methods and computer program previously described (Burger, Lee \& Rennie 1972). The intra-assay coefficients of variation (CV) for high, medium and low standard controls $11.3 \%, 8.8 \%$ and $8.2 \%$, respectively. The inter-assay CV for high, medium and low standard controls was $12.1 \%, 18.1 \%$ and $14.9 \%$, respectively. The minimum detectable concentration of progesterone was $0.12 \mathrm{ng} / \mathrm{m} \ell$.

\section{Oestradiol}

Oestradiol concentrations were measured using methods previously described (Prendiville, Enright, Crowe, Finnerty, Hynes \& Roche, 1995; Burke, Day,

TABLE 1 The sequence of treatments received by cows in the three sub-groups through the three rounds of the experiment

\begin{tabular}{|l|l|l|l|l|}
\hline \multirow{2}{*}{ Sub-group } & \multicolumn{2}{|l|}{ Round } & $\mathbf{3}$ & \multirow{2}{*}{ Sequence } \\
\cline { 2 - 5 } & $\mathbf{1}$ & $\mathbf{2}$ & None & O-G-N \\
\hline A & Oestradiol benzoate & GnRH & Oestradiol benzoate & G-N-O \\
B & GnRH & Oestradiol benzoate & GnRH & N-O-G \\
C & None & & \\
\hline
\end{tabular}


Bunt \& Macmillan 2000). Specifically, $200 \mu \ell$ aliquots of plasma and standards were extracted in $16 \mathrm{~mm} x$ $100 \mathrm{~mm}$ borosilicate glass tubes, using $2 \mathrm{~m} \ell$ diethyl ether by mixing in a multiple vortexer for a minimum of $15 \mathrm{~min}$. The tubes were transferred into a freezing methanol bath, the solvent layer was decanted into $12 \mathrm{~mm} \times 75 \mathrm{~mm}$ borosilicate glass tubes, and the solvent was evaporated in a fume hood. Standards and samples were reconstituted in $300 \mu \ell$ of assay buffer (0.1 M PBS, pH 7.0, with $0.1 \%$ gelatine and $0.1 \%$ sodium azide). The first antibody ( $50 \mu \ell$ : kit antibody diluted 1:10 in assay buffer) was added to each tube. Tubes were vortexed and incubated for $1 \mathrm{~h}$ at room temperature. Lyophilised ${ }^{125-o e s t r a d i o l-17} \beta$ was reconstituted in $20 \mathrm{~m} \ell$ assay buffer, and $50 \mu \ell$ was added to each tube; tubes were vortexed and incubated for an additional $2 \mathrm{~h}$ at room temperature. Second antibody (300 $\mu \ell$ of kit second antibody, covalently bound to magnetic particles) was added to each tube, vortexed, and incubated at room temperature for $20 \mathrm{~min}$. Placing the tubes in magnetic racks separated bound and free fractions. The supernatant was decanted and counts per minute in pellets were determined with a gamma counter. The intra-assay coefficients of variation (CV) for high, medium and low standard controls $3.5 \%, 7.9 \%$ and $7.1 \%$, respectively. The inter-assay CV for high, medium and low standard controls was $19.0 \%, 20.8 \%$ and $12.1 \%$, respectively. The minimum detectable concentration of oestradiol was $0.25 \mathrm{pg} / \mathrm{m} \ell$.

\section{Statistical analysis}

One-way analyses of variance and Fisher's least significant difference were used to compare means from each round. A cross-over design was used to analyse all rounds combined, the effects being sequence vs animal within sequence, round vs residual and treatment vs residual. The pkcross command of Stata was used (StataCorp 2001). The effect of diameter of the ovulatory follicle at the time of treatment on the diameter of the corpus luteum on Day 10 , and the progesterone concentration on Day 9 were analysed using the analysis of covariance. The interaction of treatment and the size of the ovulatory follicle, as well as cow were omitted from the statistical model, as they were not significant.

\section{RESULTS}

\section{Animals excluded from analysis}

The progesterone concentration of Cow 9898 declined from $1.14 \mathrm{ng} / \mathrm{m} \ell$ to below $1 \mathrm{ng} / \mathrm{m} \ell$ on Day -3 of Round 2. After injection of $1 \mathrm{mg}$ oestradiol benzoate on Day -1 , the progesterone concentration of Cow 9898 remained below $0.1 \mathrm{ng} / \mathrm{m} \ell$. This cow did not show behavioural signs of oestrus, did not ovulate, and did not develop a corpus luteum. This cow was excluded from the Round 2 analyses.

\section{Oestrus and follicular development}

None of the cows in the GnRH group (0/14) exhibited behavioural signs of oestrus while every cow in the control (14/14) and oestradiol benzoate groups $(13 / 13)$ exhibited behavioural signs of oestrus $(P<$ $0.01)$. All cows treated with $\mathrm{GnRH}(14 / 14)$, oestradiol benzoate (13/13) or left untreated (14/14) ovulated $(P>0.05)$. The interval from CIDR device removal to onset of oestrus did not differ between oestradiol benzoate cows and control $(44.7 \pm 5.6$ vs $46.5 \pm 7.4 \mathrm{~h}$ for oestradiol benzoate and control cows, respectively. The dominant follicle of the first follicular wave emerged earlier in the control and $\mathrm{GnRH}$ treated cows than in those treated with oestradiol benzoate $(P<0.05$, Table 2, Fig. 1). The growth rates of the first dominant follicle of cows in all the treatment groups were similar (averaged $1.24 \pm 0.05 \mathrm{~mm} /$ day, $P=0.35$, Table 2, Fig. 1). The dominant follicle ceased to grow on Day $7.3 \pm 0.2(P=0.55)$. There was early divergence in growth rate of the two largest follicles of the $\mathrm{GnRH}$ treated cows when compared to control $(P<0.05$, Table 2$)$, but not to oestradiol benzoate treated cows $(P>0.05)$. However, the day of divergence of the growth rates of the two largest follicles in the first follicular wave did not differ $(P>0.12)$.

On Day 10, diameter of the dominant follicle tended to be smaller in the oestradiol benzoate treated cows $(P=0.08$, Table 2, Fig. 1$)$.

\section{Concentration of plasma oestradiol}

The interval from emergence to peak oestradiol concentration was similar among all treatment groups $(P>0.24$, Tables 2). The peak oestradiol concentration was only different between the $\mathrm{GnRH}$ and control cows $(P<0.05$, Table 2$)$

\section{Corpus luteum and progesterone profiles}

The diameter of the corpus luteum on Day 10 and the growth rate of the follicles did not differ between the three treatment groups $(P>0.12$, Table 2, Fig. 2). The corpus luteum was detectable earlier, by ultrasonography, in the control cows compared to the either the oestradiol benzoate or $\mathrm{GnRH}$ groups $(P<0.05$, Table 2). 
The progesterone rise was earlier in control cows than in oestradiol benzoate or $\mathrm{GnRH}$ treated cows $(P<0.05$, Table 2$)$. The plasma progesterone on Day 9 was higher in the control than in oestradiol benzoate or $\mathrm{GnRH}$ treated cows $(P>0.05$, Table 2)

\section{DISCUSSION}

Treating non-lactating Holstein cows with either $1 \mathrm{mg}$ oestradiol benzoate or $250 \mu \mathrm{g}$ of $\mathrm{GnRH}$ during pro-oestrus influenced the development of the subsequent corpus luteum. Cows treated with either

TABLE 2 Follicular and corpus luteum development for all rounds combined

\begin{tabular}{|c|c|c|c|c|c|}
\hline \multirow{2}{*}{$\begin{array}{l}\text { Parameter } \\
(\text { Mean } \pm \text { SEM) }\end{array}$} & \multicolumn{3}{|l|}{ Group } & \multirow[b]{2}{*}{ Total } & \multirow[b]{2}{*}{$P^{*}$} \\
\hline & $\begin{array}{l}\text { Control } \\
(n=14)\end{array}$ & $\begin{array}{l}\text { Oestradiol benzoate } \\
(n=13)\end{array}$ & $\begin{array}{l}\text { GnRH } \\
(n=14)\end{array}$ & & \\
\hline $\begin{array}{l}\text { Size of the ovulatory } \\
\text { follicle just before } \\
\text { ovulation }(\mathrm{mm})\end{array}$ & $\begin{array}{c}16.0 \pm 0.7 b \\
(12-20)\end{array}$ & $\begin{array}{l}14.8 \pm 0.8 b \\
(11-20)\end{array}$ & $\begin{array}{c}12.6 \pm 0.8 \mathrm{a} \\
(10-19)\end{array}$ & $\begin{array}{l}14.4 \pm 0.5 \\
(10-20)\end{array}$ & 0.004 \\
\hline $\begin{array}{l}\text { Size of the ovulatory } \\
\text { follicle at treatment }(\mathrm{mm})\end{array}$ & $\begin{array}{l}12.9 \pm 0.9 a \\
(10-20)\end{array}$ & $\begin{array}{l}12.1 \pm 0.8 \mathrm{a} \\
(9-18)\end{array}$ & $\begin{array}{c}10.9 \pm 0.7 a \\
(7-18)\end{array}$ & $\begin{array}{l}11.9 \pm 0.5 \\
(7-20)\end{array}$ & 0.21 \\
\hline $\begin{array}{l}\text { Emergence day of first } \\
\text { wave dominant follicle } \\
\text { (Day) }\end{array}$ & $\begin{array}{l}0.8 \pm 0.2 a \\
\quad(0-2)\end{array}$ & $\begin{array}{l}1.7 \pm 0.9 b \\
\quad(0-3)\end{array}$ & $\begin{array}{l}0.8 \pm 0.9 a \\
\quad(0-3)\end{array}$ & $\begin{array}{l}1.1 \pm 0.9 \\
(0-3)\end{array}$ & 0.02 \\
\hline $\begin{array}{l}\text { Divergence day of first } \\
\text { wave (Day) }\end{array}$ & $\begin{array}{l}2.2 \pm 0.2 \mathrm{a} \\
\quad(1-3)\end{array}$ & $\begin{array}{c}2.8 \pm 0.3 a b \\
(1-6)\end{array}$ & $\begin{array}{l}3.0 \pm 0.3 b \\
\quad(2-5)\end{array}$ & $\begin{array}{l}2.7 \pm 0.2 \\
\quad(1-6)\end{array}$ & 0.10 \\
\hline $\begin{array}{l}\text { Day of reduction of } \\
\text { growth of the first } \\
\text { dominant follicle (Day) }\end{array}$ & $\begin{array}{l}7.6 \pm 0.3 a \\
\quad(6-9)\end{array}$ & $\begin{array}{l}7.2 \pm 0.2 \mathrm{a} \\
\quad(6-8)\end{array}$ & $\begin{array}{l}7.1 \pm 0.3 a \\
(6-10)\end{array}$ & $\begin{array}{c}7.3 \pm 0.2 \\
(6-10)\end{array}$ & 0.55 \\
\hline $\begin{array}{l}\text { Diameter of the first } \\
\text { dominant follicle on } \\
\text { Day } 10(\mathrm{~mm})\end{array}$ & $\begin{array}{c}15.6 \pm 0.8 a b \\
(10-20)\end{array}$ & $\begin{array}{c}14.3 \pm 0.5 a \\
(12-18)\end{array}$ & $\begin{array}{c}16.3 \pm 0.7 b \\
(10-20)\end{array}$ & $\begin{array}{c}15.4 \pm 0.4 \\
(10-20)\end{array}$ & 0.08 \\
\hline $\begin{array}{l}\text { Growth rate of the first } \\
\text { dominant follicle } \\
\text { (mm/day) }\end{array}$ & $\begin{array}{l}1.18 \pm 0.08 a \\
(0.63-1.67)\end{array}$ & $\begin{array}{c}1.23 \pm 0.07 a \\
(0.90-1.75)\end{array}$ & $\begin{array}{c}1.31 \pm 0.09 a \\
(0.60-2.14)\end{array}$ & $\begin{array}{l}1.24 \pm 0.05 \\
(0.60-2.14)\end{array}$ & 0.35 \\
\hline $\begin{array}{l}\text { First day corpus luteum } \\
\text { detected, days (Day) }\end{array}$ & $\begin{array}{l}2.6 \pm 0.3 a \\
\quad(1-4)\end{array}$ & $\begin{array}{l}3.1 \pm 0.2 b \\
\quad(2-4)\end{array}$ & $\begin{array}{l}3.3 \pm 0.2 b \\
\quad(2-4)\end{array}$ & $\begin{array}{l}3.0 \pm 0.1 \\
\quad(1-4)\end{array}$ & 0.02 \\
\hline $\begin{array}{l}\text { Diameter of corpus } \\
\text { luteum on Day } 10(\mathrm{~mm})\end{array}$ & $\begin{array}{c}25.5 \pm 1.1 \mathrm{a} \\
(20-30)\end{array}$ & $\begin{array}{c}23.1 \pm 0.7 a \\
(19-28)\end{array}$ & $\begin{array}{l}22.4 \pm 1.2 \mathrm{a} \\
\quad(17-34)\end{array}$ & $\begin{array}{c}23.7 \pm 0.6 \\
(17-34)\end{array}$ & 0.12 \\
\hline $\begin{array}{l}\text { Growth rate of the } \\
\text { corpus luteum (mm/day) }\end{array}$ & $\begin{array}{l}1.9 \pm 0.2 a \\
(0.3-2.6)\end{array}$ & $\begin{array}{l}1.8 \pm 0.5 a \\
(0.5-2.3)\end{array}$ & $\begin{array}{l}1.8 \pm 1.0 \mathrm{a} \\
(0.3-4.3)\end{array}$ & $\begin{array}{l}1.8 \pm 0.7 \\
(0.3-4.3\end{array}$ & 0.99 \\
\hline $\begin{array}{l}\text { Maximum plasma pro- } \\
\text { gesterone concentration } \\
\text { on Day } 9(\mathrm{ng} / \mathrm{m} \ell)\end{array}$ & $\begin{array}{l}5.0 \pm 0.3 b \\
(2.7-8.3)\end{array}$ & $\begin{array}{c}3.6 \pm 0.2 \mathrm{a} \\
(2.6-5.2)\end{array}$ & $\begin{array}{c}3.6 \pm 0.4 a \\
(1.4-6.6)\end{array}$ & $\begin{array}{l}4.0 \pm 0.2 \\
(1.4-8.3)\end{array}$ & 0.02 \\
\hline $\begin{array}{l}\text { Progesterone } \\
\text { rise (ng/m } / / \text { day) }\end{array}$ & $\begin{array}{l}1.22 \pm 0.12 b \\
(0.68-2.07)\end{array}$ & $\begin{array}{c}0.88 \pm 0.06 a \\
(0.64-1.30)\end{array}$ & $\begin{array}{c}0.87 \pm 0.10 a \\
(0.31-1.62)\end{array}$ & $\begin{array}{l}0.99 \pm 0.06 \\
(0.31-2.07)\end{array}$ & 0.02 \\
\hline $\begin{array}{l}\text { Maximum plasma } \\
\text { oestradiol concentration } \\
(\mathrm{pg} / \mathrm{m} \ell)\end{array}$ & $\begin{array}{l}1.4 \pm 0.1 \mathrm{a} \\
(0.9-2.5)\end{array}$ & $\begin{array}{l}1.7 \pm 0.1 \mathrm{ab} \\
(1.1-2.6)\end{array}$ & $\begin{array}{l}2.0 \pm 0.3 b \\
(1.0-4.0)\end{array}$ & $\begin{array}{l}1.7 \pm 0.1 \\
(0.9-4.0)\end{array}$ & 0.10 \\
\hline $\begin{array}{l}\text { Interval to peak oestradiol } \\
\text { plasma concentration } \\
\text { post-ovulation (days) }\end{array}$ & $\begin{array}{l}5.7 \pm 0.3 a \\
\quad(5-7)\end{array}$ & $\begin{array}{l}5.5 \pm 0.2 a \\
\quad(5-7)\end{array}$ & $\begin{array}{l}5.3 \pm 0.2 a \\
\quad(5-7)\end{array}$ & $\begin{array}{l}5.5 \pm 0.1 \\
\quad(5-7)\end{array}$ & 0.43 \\
\hline
\end{tabular}

${ }^{*} P \quad$ Value derived from the crossover analysis

$a, b$ Means with common superscripts did not differ at a significance level of 0.05 


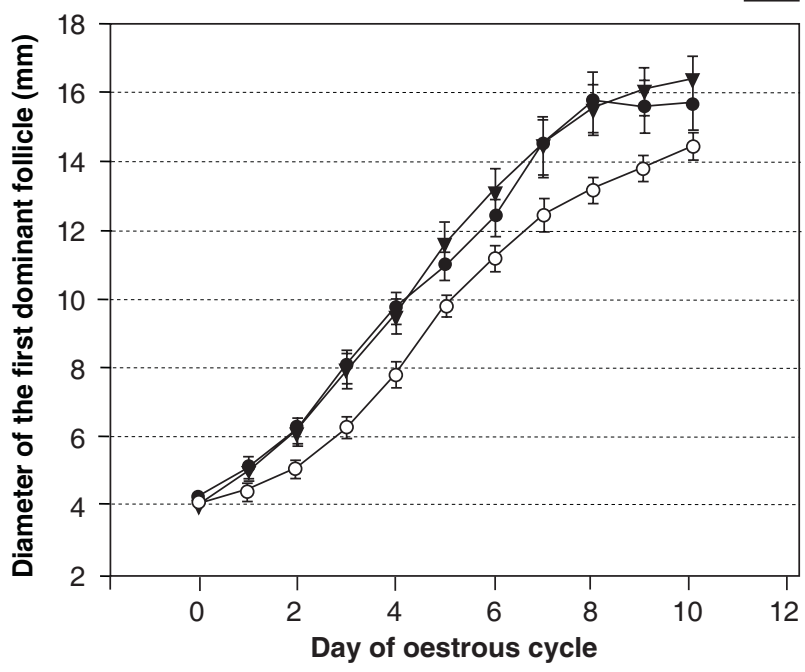

B

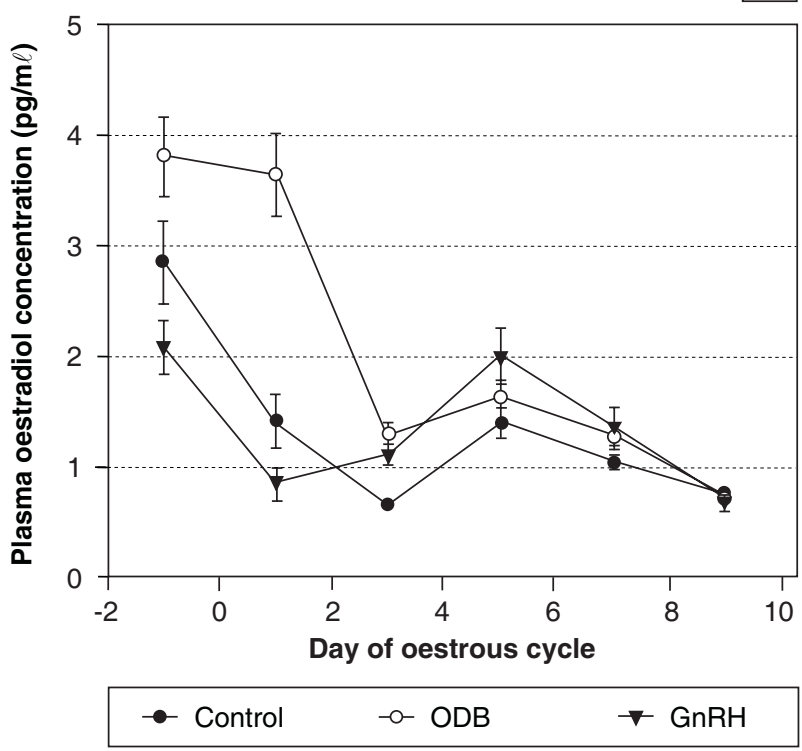

FIG. 1 Mean diameter of the first dominant follicle $(A)$ and plasma oestradiol $17 \beta(B) \pm$ SEM during the combined rounds

$1 \mathrm{mg}$ oestradiol benzoate or $250 \mu \mathrm{g} \mathrm{GnRH}$ had a significantly smaller corpus luteum on Day 10; this corpus luteum secreted less progesterone than the corpus luteum formed after cows ovulated spontaneously. The consistent association of the treatment groups with the smaller corpus luteum strongly suggested an effect of induction of ovulation 24 or $36 \mathrm{~h}$ after CIDR device removal with oestradiol benzoate and $\mathrm{GnRH}$, respectively.

These findings support the hypothesis that the development of corpus luteum in cows treated with

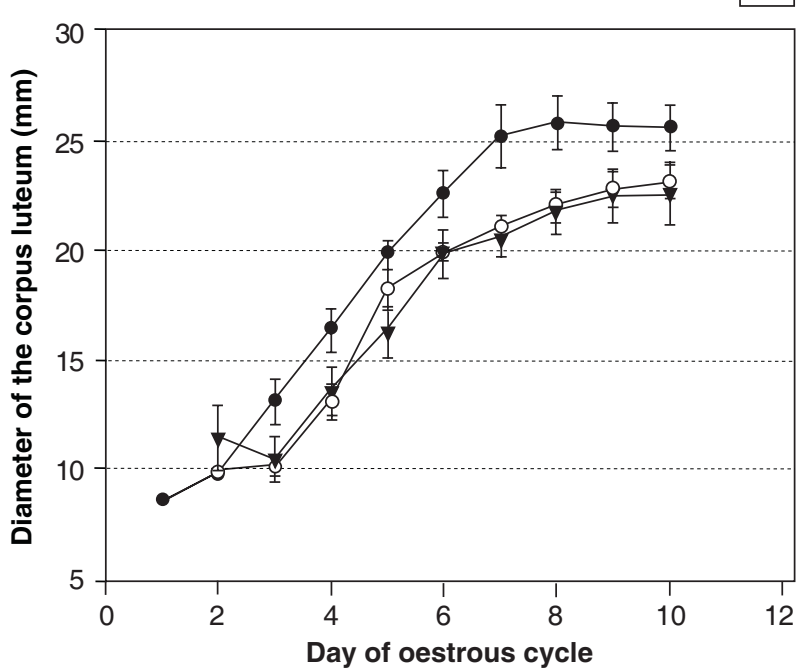

B

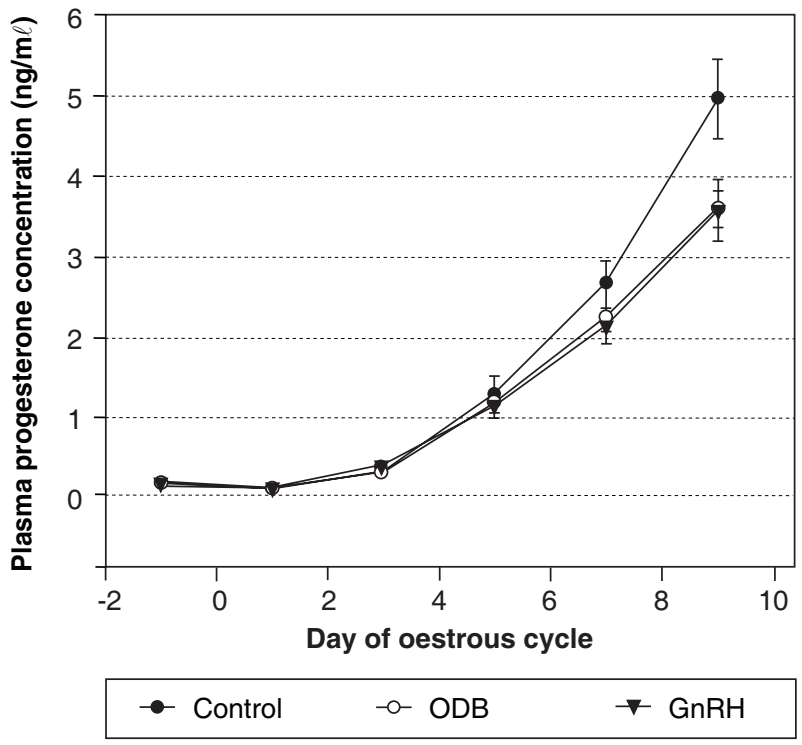

FIG. $\quad 2$ Mean diameter of the corpus luteum (A) and plasma progesterone concentration (B) \pm SEM of the three treatment groups during Days 1-10 for all rounds combined

$\mathrm{GnRH}$ and oestradiol benzoate at pro-oestrus was similar. However, the findings that control cows had a larger corpus luteum on Day 10 than that of cows treated with $\mathrm{GnRH}$ or oestradiol benzoate was unexpected. The reasons for this outcome remain unclear. Reduced plasma concentrations of progesterone in cattle during the luteal phase following ovulation with a $\mathrm{GnRH}$ agonist compared to spontaneous oestrus has previously been reported (Schmitt et al. 1996); in those studies, cows that had been treated with $\mathrm{GnRH}$ at pro-oestrus and subsequently 
had lower progesterone concentration also experienced short oestrous cycles. In the current study, the progesterone concentrations with corpus luteum diameter differed only on Days 9 or 10 for progesterone concentration and corpus luteum diameter, respectively. Transrectal ovarian ultrasonography and blood sampling were discontinued on Days 9 and 10 of each round, respectively; therefore, the ovarian function after Day 10 could not be described. Future studies should perform similar trials and sequentially examine ovarian structures and steroids for the entire oestrous cycle in order to account for the effect of induction of a dominant follicle on ovarian function after Day 10.

The experiment was not designed to produce ovulatory follicles of different sizes at the time of administration of the pro-oestrous treatments. It was therefore not surprising that these follicles were similar at the time of the pro-oestrous treatments. Interestingly, the final measured diameter of the ovulatory follicles was smaller in $\mathrm{GnRH}$ treated cows than when cows were either not treated or treated with oestradiol benzoate, when all rounds were combined (Table 2). The ovulatory follicle diameter just prior to ovulation was left as an observation, and could not be included in the analysis as a covariate, or in the linear regression that analysed the relationship of the ovulatory follicle with the either the diameter of the corpus luteum on Day 10 or progesterone concentration on Day 9. This was due to the likelihood of a treatment effect that had been given 2 days prior to ovulation in the majority of cows. However, when the size of the ovulatory follicle at the time of treatment was added to the analysis, there was a relationship with the plasma progesterone concentration on Day 10, but not with the diameter of the corpus luteum on Day 9. These results must be interpreted with caution due to the low power of the performed tests. Other studies have found an association between the maturity of the ovulatory follicle and the subsequent corpus luteum function has been reported previously (Burke, Mussard, Grum \& Day 2001).

The physiological importance of higher concentration of progesterone within the first days after ovulation is equivocal. While some workers reported that lower progesterone concentrations before, but not after insemination, were associated with lower fertility (Vasconcelos, Silcox, Rosa, Pursley \& Wiltbank 1999), it has also been shown that the early rise in plasma progesterone concentration within 5 days after Al was positively correlated with the mechanism of maternal recognition of pregnancy (Mann \& Lamming 1999). Supporting the latter study is the recent report that pregnancy rates were lower in cows treated with oestradiol benzoate when the new wave had just emerged compared to when the newly emerged follicle ovulated spontaneously; the ovulatory follicle was smaller when it had just emerged, compared to oestradiol benzoate administration at dominance (Lane, Austin, Roche \& Crowe 2001). Perhaps this lowered fertility was due to the corpus luteum development post-ovulation, as seen in this study. Synchronization protocols are usually initiated when the cows are at different stages in terms of ovarian follicular development. The relevance of the present study is that the subsequent corpus luteum may be partly compromised in cows where treatments for induction of ovulation are done when the follicle has only recently emerged. The concept of synchronization of emergence of a new wave as described previously (Burke et al. 2000), could become most important so that the fertility of the ovulatory follicle was not compromised by the induction of ovulation with oestradiol benzoate or $\mathrm{GnRH}$.

There was a tendency for the corpus to be detected earlier when cows were in the control group. No reason was evident why these corpus luteuma were detected earlier in this group. On average, the corpus luteuma were first detected on Day $3.0 \pm 0.1$ (range 1.0-4.0; Table 2). This is in agreement with other studies (Singh, Pierson \& Adams 1997; Kot \& Ginther 1999). Although the corpus luteuma may start to form soon after ovulation (Reynolds \& Redmond 1999), the most intensive growth in luteal tissue will occur between Days 3 and 4 (Kot \& Ginther 1999); changes in echogencity and histomorphology occur by Day 3 (Singh et al. 1997), corresponding with the increase in plasma concentrations that occurs at this time (Wiltbank, Shiao, Bergflet \& Ginther 1995).

Treating non-lactating cycling Holstein cows with $1 \mathrm{mg}$ oestradiol benzoate at pro-oestrus delayed wave emergence of the subsequent cycle by 0.9 days. This delay was less than that reported in other studies (Burke et al. 2000). In addition, the first dominant follicle reportedly emerges on average between Days 0.2 to 4 of ovulation (Knopf, Kastelic, Schallenberger \& Ginther 1989). The emergence of the new follicle of cows in the control group in the current study was within this normal range limiting any physiological significance of the delay. Perhaps the magnitude of the delay when oestradiol benzoate was injected at pro-oestrus could be due to the minor role of oestradiol in the control of FSH during the periovulatory period (Findlay, Clarke \& Robertson 1990). Studies using ovariectomised cow models (Kesner 
\& Convey 1982) or immuno-neutralisation against either oestrogen or inhibin (Kaneko, Nakanashi, Akagi, Arai, Taya, Watanabe, Sasamoto \& Hasegawa 1995) support the role of inhibin, but not oestradiol, in the control of FSH secretion during the preovulatory period. Also, suppression of the FSH surge with charcoal-extracted bovine follicular fluid delayed emergence of a new wave by 2 days (Turzillo \& Fortune 1990). Collectively, these series of studies showed that oestradiol had a positive feedback effect on the secretions of FSH during the follicular phase, but exert a minor effect in suppressing $\mathrm{FSH}$ secretion in the absence of inhibin during the 24-h period following the preovulatory LH surge. It is therefore proposed that the slight delay in the suppression of emergence of the next wave in cows treated with $1 \mathrm{mg}$ oestradiol benzoate at pro-oestrus was due to the decline in inhibin around ovulation; hence, the secondary FSH surge, which is thought to play a role in recruitment of a new cohort of ovarian follicles (Kaneko, Watanabe, Taya \& Sasamoto 1992), was minimally suppressed, in every cow treated with oestradiol benzoate.

There were no differences in the time from ovulation to the plasma maximum oestradiol concentration between the three treatment groups. These similarities cast further doubts on the significance of the delayed follicular emergence of oestradiol benzoatetreated cows in relation to subsequent follicular development. It would be expected that delayed follicular emergence would have delayed the peak oestradiol concentration. When follicular emergence was delayed by 2 days in cows treated with charcoal extracted bovine follicular fluid, there was an associated delay in the interval from ovulation to peak plasma oestradiol concentrations (Turzillo \& Fortune 1990). Interestingly, the peak plasma oestradiol concentration occurred on Day 5 and began declining by Day 7 . This decline in plasma oestradiol concentration coincided with the time when the dominant follicle reduced in its growth rate in each of the treatment groups. This is in agreement with a one study that showed that the morphological appearance of a dominant follicle was positively correlated with its functionality (Ali, Lange, Gilles \& Glatzel 2001). This decline in plasma oestradiol also coincided with the time when a new follicular wave usually emerged in three-wave cycles (Knopf et al. 1989). In this study, ultrasonography was not continued for sufficient time to retrospectively identify the emergence of a new follicular wave between Days 6 and 10. However, since by definition, dominance of a follicle is lost when a new wave emerges (Ireland, Mihm, Austin, Diskin \& Roche 2000), and the decrease in plasma oestradiol on Day 7 indicated this loss of dominance was similar to that reported previously (Rhodes, Fitzpatrick, Entwistle \& Kinder 1995).

None of the GnRH treated cows exhibited behavioural signs of oestrus, while all of the controls and oestradiol benzoate treated cows did show behavioural signs of oestrus. This effect of $\mathrm{GnRH}$ has been reported in other studies (McDougall, Cullum, Anniss \& Rhodes 2001). The preovulatory LH surge released by $\mathrm{GnRH}$ decreased the concentration of serum and intrafollicular oestradiol within $1 \mathrm{~h}$ of treatment (Kobayashi, Coe \& Stevenson 1995), consequently inhibiting the expression of oestrus (Stevenson, Hoffman, Nichols, Mckee \& Krehbiel 1997). Expression of oestrus in cows can be affected by whether or not the minimum threshold concentration of oestradiol in plasma required to induce oestrous behaviour has been achieved (Glencross, Esslemont, Bryant \& Pope 1981). It was not surprising that none of the $\mathrm{GnRH}$-treated cows in the present study exhibited behavioural signs of oestrus. Other authors have found that with the Ovsynch protocol, $30 \%$ of cows may show some behavioural signs of oestrus before the second injection of GnRH (Stevenson, Kobayashi \& Thompson 1999). This will occur in a population of cows where the first $\mathrm{GnRH}$ in the Ovsynch protocol has been administered randomly to cows at various stages of the follicular development.

In summary, induction of ovulation with either oestradiol benzoate or $\mathrm{GnRH}$ resulted in synchronized ovulation. Cows that were induced to ovulate with oestradiol benzoate had delayed emergence of the new follicular wave (by 0.9 days) compared to $\mathrm{GnRH}$-treated or control cows. Dominant follicle that ovulated spontaneously were larger than those induced to ovulate with either oestradiol benzoate or $\mathrm{GnRH}$. Consequently, the corpus luteum of cows that ovulated spontaneously had a greater growth rate, resulting in a significantly larger corpus lutea on Day 10. This corpus lutea secreted more progesterone than those formed when cows had been induced to ovulate with either $\mathrm{GnRH}$ or oestradiol benzoate. These induced ovulations were followed by different patterns of corpus lutea development.

One implication of findings from the present study is that induction of ovulation with either oestradiol benzoate or $\mathrm{GnRH}$, administered 24 (oestradiol benzoate) or $36 \mathrm{~h}(\mathrm{GnRH})$ after withdrawal of the CIDR device, respectively may lower fertility. The effect of this induction on the corpus lutea development after Day 10 needs to be studied. In addition, future stud- 
ies must identify the timing of administration relative to the time of CIDR device withdrawal and the optimum concentration of oestradiol benzoate or $\mathrm{GnRH}$ that would not have untoward effects on the development of the corpus lutea, particularly within the first week of dioestrus.

\section{REFERENCES}

ADAMS, G.P. 1998. Control of ovarian follicular wave dynamics in mature and prepubertal cattle for synchronization \& superstimulation. Proceedings of the XXth World Buiatrics Conference, Sydney 6-10 July 1998 2:595-605.

ALI, A., LANGE, A., GILLES, M. \& GLATZEL, P.S. 2001. Morphological and functional characteristics of the dominant follicle and corpus luteum in cattle and their influence on ovarian function. Theriogenology, 56:569-576.

BURGER, H.G., LEE, V.W. \& RENNIE, G.C. 1972. A generalized computer program for the treatment of data from competitive protein-binding assays including radioimmunoassays. Journal of Laboratory Clinical Medicine, 80:302-312.

BURKE, C.R., DAY, M.L., BUNT, C.R. \& MACMILLAN, K.L. 2000. Use of a small dose of estradiol benzoate during diestrus to synchronize development of the ovulatory follicle in cattle. Journal of Animal Science, 78:145-151.

BURKE, C.R., MUSSARD, M.L., GRUM, D.E. \& DAY, M.L. 2001. Effects of maturity of the potential ovulatory follicle on induction of oestrus and ovulation in cattle with oestradiol benzoate. Animal Reproduction Science, 66:161-174.

DAY, M.L., BURKE, C.R., TAUFA, V.K., DAY, A.M. \& MACMILLAN, K.L. 2000. The strategic use of estradiol to enhance fertility and submission rates of progestin-based estrus synchronization programs in dairy herds. Journal of Animal Science, 78:523-529.

FIKE, K.E., DAY, M.L., INSKEEP, E.K., KINDER, J.E., LEWIS, P.E., SHORT, R.E. \& HAFS, H.D. 1997. Estrus and luteal function in suckled beef cows that were anestrous when treated with an intravaginal device containing progesterone with or without a subsequent injection of estradiol benzoate. Journal of Animal Science, 75:2009-2015.

FINDLAY, J.K., CLARKE, I.J. \& ROBERTSON, D.M. 1990. Inhibin concentrations in ovarian and jugular venous plasma and the relationship of inhibin with follicle-stimulating hormone and luteinizing hormone during the ovine estrous cycle. Endocrinology, 126:528-535.

GLENCROSS, R.G., ESSLEMONT, R.J., BRYANT, M.J. \& POPE, G.S. 1981. Relationship between the incidence of preovulatory behaviour and the concentrations of oestradiol-17b and progesterone in plasma. Applied Animal Ethology, 7: 141-148.

HANLON, D.W., WILLIAMSON, N.B., WICHTEL, J.J., STEFFERT, I.J., CRAIGIE, A.L. \& PFEIFFER, D.U. 1996. The effect of estradiol benzoate administration on estrous response and synchronized pregnancy rate in dairy heifers after treatment with exogenous progesterone. Theriogenology, 45:775785.

IRELAND, J.J., MIHM, M., AUSTIN, E., DISKIN, M.G. \& ROCHE, J.F. 2000. Historical perspective of turnover of dominant follicles during the bovine estrous cycle: key concepts, studies, advancements, and terms. Journal of Dairy Science, 83: 1648-1658.
KANEKO, H., NAKANISHI, Y., AKAGI, S., ARAI K., TAYA, K., WATANABE, G., SASAMOTO, S. \& HASEGAWA, Y. 1995. Immunoneutralization of inhibin and estradiol during the follicular phase of the estrous cycle in cows. Biology of Reproduction, 53:931-939.

KANEKO, H., WATANABE, G., TAYA, K. \& SASAMOTO, S. 1992. Changes in peripheral levels of bioactive and immunoreactive inhibin, estradiol-17 beta, progesterone, luteinizing hormone, and follicle-stimulating hormone associated with follicular development in cows induced to superovulate with equine chorionic gonadotropin. Biology of Reproduction, 47: 76-82.

KESNER, J.S. \& CONVEY, E.M. 1982. Interaction of estradiol and luteinizing hormone releasing hormone on follicle stimulating hormone release in cattle. Journal of Animal Science, 54:817-821.

KNOPF, L., KASTELIC, J.P., SCHALLENBERGER, E. \& GINTHER, O.J. 1989. Ovarian follicular dynamics in heifers: test of two-wave hypothesis by ultrasonically monitoring individual follicles. Domestic Animal Endocrinology, 6:111-119.

KOBAYASHI, Y., COE, M.L. \& STEVENSON, J.S. 1995. Changes in characteristics of the bovine pre-ovulatory follicle after $\mathrm{GnRH}$ administration at estrus. Journal of Animal Science, Supplement, 73:220.

KOT, K. \& GINTHER, O.J. 1999 Ultrasonic characterization of ovulatory follicular evacuation and luteal development in heifers. Journal of Reproduction and Fertility, 115:39-43.

LANE, E.A., AUSTIN, E.J., ROCHE, J.F. \& CROWE, M.A. 2001. The effect of estradiol benzoate on synchrony of estrus and fertility in cattle after removal of a progesterone-releasing intravaginal device. Theriogenology, 55:1807-1818.

LUCY, M.C. \& STEVENSON, J.S. 1986. Gonadotropin-releasing hormone at estrus: luteinizing hormone, estradiol, and progesterone during the periestrual and postinsemination periods in dairy cattle. Biology of Reproduction, 35:300-311.

MANN, G.E. \& LAMMING, G.E. 1999. The Influence of progesterone during early pregnancy in cattle. Reproduction in Domestic Animals, 34:269-273.

MCDOUGALL, S., CULLUM, A.A., ANNISS, F.M. \& RHODES, F.M. 2001. Treatments of anovulatory anoestrous postpartum dairy cows with a gonadotrophin-releasing hormone agonist $\mathrm{GnRH}$, prostaglandin $\mathrm{F} 2 \mathrm{a}, \mathrm{GnRH}$ regime or with progesterone and oestradiol benzoate. New Zealand Veterinary Journal, 45:168-172.

MEE, M.O., STEVENSON, J.S., ALEXANDER, B.M. \& SASSER, R.G. 1993. Administration of $\mathrm{GnRH}$ at estrus influences pregnancy rates, serum concentrations of $\mathrm{LH}, \mathrm{FSH}$, estradiol-17 beta, pregnancy-specific protein $\mathrm{B}$, and progesterone, proportion of luteal cell types, and in vitro production of progesterone in dairy cows. Journal of Animal Science, 71:185198.

MOREIRA, F., DE LA SOTA, R.L., DIAZ, T. \& THATCHER, W.W. 2000. Effect of day of the estrous cycle at the initiation of a timed artificial insemination protocol on reproductive responses in dairy heifers. Journal of Animal Science, 78:15681576.

PETERS, A.R., WARD, S.J., WARREN, M.J., GORDON, P.J., MANN, G.E. \& WEBB, R. 1999. Ovarian and hormonal responses of cows to treatment with an analogue of gonadotrophin releasing hormone and prostaglandin F2 alpha. Veterinary Record, 144:343-346.

PRENDIVILLE, D.J., ENRIGHT, M.J., CROWE, M.A., FINNERTY, M., HYNES, N. \& ROCHE, J.F. 1995. Immunization of heifers against gonadotropin-releasing hormone antibody titers, 
ovarian function, body growth and carcass characteristics. Journal of Animal Science, 73:2382-2389.

PURSLEY, J.R., WILTBANK, M.C., STEVENSON, J.S., OTTOBRE, J.S., GARVERICK, H.A. \& ANDERSON, L.L. 1997. Pregnancy rates per artificial insemination for cows and heifers inseminated at a synchronized ovulation or synchronized estrus. Journal of Dairy Science, 80:295-300.

REYNOLDS, J.P. \& REDMOND, D.A. 1999. Growth and development of the corpus luteum. Journal of Reproduction and Fertility Supplement, 54:181-191.

RHODES, F.M., FITZPATRICK, L.A., ENTWISTLE, K.W. \& KINDER, J.E. 1995. Hormone concentrations in the caudal vena cava during the first ovarian follicular wave of the oestrous cycle in heifers. Journal of Reproduction and Fertility, 104:33-39.

RIVERA, G.M., GONI, C.G., CHAVES, M.A., FERRERO, S.B. \& BO, G.A. 1998. Ovarian follicular wave synchronization and induction of ovulation in postpartum beef cows. Theriogenology, 49:1365-75.

SCHMITT, E.J., DIAZ, T., DROST, M. \& THATCHER, W.W. 1996. Use of a gonadotropin-releasing hormone agonist or human chorionic gonadotropin for timed insemination in cattle. Journal of Animal Science, 74:1084-91.

SINGH, J., PIERSON, R.A. \& ADAMS, G.P. 1997. Ultrasound image attributes of the bovine corpus luteum: structural and functional correlates. Journal of Reproduction and Fertility, 109:35-44.

STATACORP 2001. Stata Statistical Software Release 7.0. College Station, TX: Stata Corporation.
STEVENSON, J.S., HOFFMAN, D.P., NICHOLS, D.A., MCKEE, R.M. \& KREHBIEL, C.L. 1997. Fertility in estrus-cycling and noncycling virgin heifers and suckled beef cows after induced ovulation. Journal of Animal Science, 75:1343-1350.

STEVENSON, J.S., KOBAYASHI, Y. \& THOMPSON, K.E. 1999. Reproductive performance of dairy cows in various programmed breeding systems including OvSynch and combinations of gonadotropin-releasing hormone and prostaglandin F2 alpha. Journal of Dairy Science, 82:506-515.

TAPONEN, J., KATILA, T. \& RODRIGUEZ-MARTINEZ, H. 1999. Induction of ovulation with gonadotropin-releasing hormone during proestrus in cattle: influence on subsequent follicular growth and luteal function. Animal Reproduction Science, 55:91-105.

TAPONEN, J., RODRIGUEZ-MARTINEZ, H. \& KATILA, T. 2000. Administration of gonadotropin-releasing hormone during metoestrus in cattle: influence on luteal function and cycle length. Animal Reproduction Science, 64:161-169.

TURZILLO, A.M. \& FORTUNE, J.E. 1990. Suppression of the secondary FSH surge with bovine follicular fluid is associated with delayed ovarian follicular development in heifers. Journal of Reproduction and Fertility, 89:643-653.

VASCONCELOS, J.L., SILCOX, R.W., ROSA, G.J., PURSLEY, J.R. \& WILTBANK, M.C. 1999. Synchronization rate, size of the ovulatory follicle, and pregnancy rate after synchronization of ovulation beginning on different days of the estrous cycle in lactating dairy cows. Theriogenology, 52:1067-1078.

WILTBANK, M.C., SHIAO, T.F., BERGFELT, D.R. \& GINTHER, O.J. 1995. Prostaglandin F2 alpha receptors in the early bovine corpus luteum. Biology of Reproduction, 52:74-78. 